\title{
Technological Innovation and Strategic Leadership Axis on Competitive Advantage of Telecommunication Enterprises
}

\author{
Perpetua S. Wanaswa ${ }^{1}$, Zachary B. Awino ${ }^{2}$, Martin Ogutu ${ }^{3} \&$ Joseph Owino $^{4}$ \\ ${ }^{1} \mathrm{PhD}$ Candidate, School of Business, University of Nairobi, Kenya \\ ${ }^{2}$ Professor of Strategy-Innovation and Performance Management, School of Business, University of Nairobi, \\ Kenya \\ ${ }^{3}$ Associate Professor, School of Business, University of Nairobi, Kenya \\ ${ }^{4}$ Lecturer, School of Business, University of Nairobi, Kenya \\ Correspondence: Perpetua S. Wanaswa, PhD Candidate, School of Business, University of Nairobi, Kenya. \\ E-mail: sidipw1@gmail.com
}

Received: May 21, 2021

Accepted: July 23, 2021

Online Published: August 3, 2021

doi:10.5539/ijbm.v16n9p48

URL: https://doi.org/10.5539/ijbm.v16n9p48

\begin{abstract}
The study conceptualized a relationship between technological innovation and strategic leadership on competitive advantage. Technological innovation has been posited to influence performance competitive advantage however; this position has been largely tautological and hence required more empirical testing. Although implied, the role of strategic leadership in the relationship between technological innovation and competitive advantage has been largely lacking. The study, therefore, specifically sought to determine the moderating role of strategic leadership on the relationship between technological innovation and competitive advantage of large telecommunication enterprises (LTEs) in Kenya. Significant transformations have been evident in Kenya's telecommunication industry for the last two decades, which has resulted in intense competition, and technological innovation has become the new face of competition among these firms. The target population comprised all 83 large telecommunication enterprises in Kenya and census was used. Both descriptive and inferential statistics were employed in data analysis. Strategic leadership was found to have a positive and significant influence on the relationship between technological innovation and competitive advantage. It is deduced from the findings that strategic leadership would affect the strength of the relationship between technological innovation and competitive advantage. This can be attributed to the importance of organizational leadership's role as decision makers and key enablers of technological innovation among large telecommunication enterprises. The study presented notable implications on the policy framework, the strategic management practice, and theory implications in the telecommunication industry and beyond. At policy level, the Government of Kenya would benefit from the study by ensuring that policy makers and regulatory authorities in the telecommunication sector formulate policies that would promote technological innovation and strategic leadership for enhancing competitive advantage. Managerial practitioners may consider institutionalizing innovation and leadership by creating the requisite direction and controls that enable the emergence of innovation and value creation for sustainable competitive advantage. The study findings' implications further extended, supported, and added value on the theories adopted by the study.
\end{abstract}

Keywords: Technological innovation, strategic leadership, large telecommunication enterprises, competitive advantage

\section{Introduction}

Enterprises are perpetually keen on competition. Enterprises are competing with one another on the basis of ability to innovate through utilization of knowledge-based resources. Increasingly dynamic and competitive forces of the environment require the ability of business leaders to strategically and proactively manage resources in their control in the form of knowledge assets if they are to achieve desired strategic innovation capability and competitive advantage (Kuusisto \& Meyer, 2015; Miles, 2016). Strategic leadership is, therefore, paramount as it helps in identification of organizational direction and controls vision, as well as growth.

In today's fast-changing business environment, characterized by increasing globalization, rapid technological 
changes and newer lifestyles, firms that want to remain competitive must be innovative. Technological innovation is not simply developing new technologies into new products or services, but in many cases involves finding new models for doing business in the face of change, contemporary, and dynamic world. It often entails changing the rules of the game by the strategic leadership. Modern firms are increasingly engaging in constant competition with rivals having a goal to survive on the market; therefore, their strategic leadership must formulate well aligned innovative strategies in order to meet customer demands and a significant form of growth. It is in this aspect that strategic leadership of these enterprises regularly considers how they can improve their competitive edge by developing and putting into practice various business strategies (Herden, 2020).

Further, considering the modern global economy that is increasingly competitive, with the basis of competition tilting more and more towards technological innovation, competitive advantage is generated and sustained through highly localized national processes. Doing this requires strong strategic leadership. Leadership that believes in change and importance of technological innovation, leadership capable of energizing enterprises to innovate continuously, and a leadership that recognizes the critical importance of their home country as integral to their competitive success hence work to improve it. The hard questions at any strategic leadership's countenance enterprises are deciding what technological innovations are suitable for the chosen strategy to pursue (Awino, 2013).

Technological innovation in the telecommunication industry should be implemented to enhance competitive advantage. In order for a firm to have a competitive advantage, technological innovation and strategic leadership are most important. As the decision makers, organizational leaders determine the extent to which technological innovation takes place in an organization which in turn influence the competitive advantage thereof. It is worthwhile noting that change in strategic leadership would affect the strength of the relationship between technological innovation and competitive advantage. This can be attributed to the importance of organizational leadership's role as shaping strategic direction, organization controls, decision makers, and key enablers of technological innovation among telecommunication firms in Kenya through support by resource mobilization, mentorship, recognition, and provision of autonomy among staff to innovate.

The relationship between technological innovation and competitive advantage has elicited a vibrant conversation among strategic management scholars and practitioners since the seminal works of Rogers (1983) and Porter (1985). Studies have shown that technological innovation influence competitive advantage (Mugo \& Macharia, 2020) but it has also been contended that technological innovation cannot singly influence competitive advantage but have to be combined with other variables including strategic leadership.

The concept of competitive advantage has been studied extensively by a plethora of scholars (Awino, 2013; Adede, Kibera \& Owino, 2017) in association with a wide array of antecedents. Whereas literature in place has focused on the direct linkage between the concepts of competitive advantage and strategic leadership (Gathi, 2018; Kising'u, 2017); and technological innovation (Kiptui, 2017; Nyawade, 2015; Yalla, 2015) limited studies have examined both the direct and indirect associations among the concepts of technological innovation, strategic leadership, and the ability of firms to remain competitive in one conceptual model. This has presented a conceptual gap in literature motivating the study.

The contextual motivation for the study was the growing competition among large telecommunication firms in Kenya with the highest market concentration of one player controlling nearly $70 \%$ of the industry's share and value (CA, 2020). In the long term, this was harmful to the economy as it limited competition and investments putting consumers at risk. It was, therefore, important that the strategies employed by the large telecommunication firms to earn competitive advantage in such a highly concentrated market yet unbalanced in terms of dominance are identified hence the need for the study.

On a global perspective, a study in Britain on telecommunications forecasting by Oughton et. al., (2018) that zeroed-in on fast-evolving technologies found that demand, supply, and the market scenario in Britain were affected by technological innovation. The methodology involved the use of an open-source modelling framework that could forecast technology diffusion in Britain between the years 2016 and 2030 whereas the current study adopted cross sectional survey and multiple regression presenting a methodological gap. The study did not take into account all the concepts in the current study and was done in Britain and findings could not apply to the current study as it was done in the Kenyan context and, therefore, seeking to offer answers to the following research question: what is the influence of strategic leadership on the relationship between technological innovation and competitive advantage among telecommunication enterprises?

\section{Materials}

The study is anchored on technological networks theory of innovation formulated by Rogers (1983). The theory 
holds that technological innovation is driven on both internal and external ways. Owing to its overarching description of all the present study variables, the theory is selected as the anchoring theory. In today's global knowledge economy, technological innovation as a process comprises of social interaction as opposed to individual achievement. This implies that innovation integrates both formal and informal associations between firms and organizations on the one hand. On the other hand, innovation involves different actors interacting within networks. Therefore, various intangible forms of capital and social relationships combine to bring about innovation (Karlsson et al., 2013).

In order to sustain dynamic capabilities, Teece (2012) argued that strategic leadership would need to have business and leadership skills. These must comprise the sensing, seizing, and transforming elements. This implied that achieving semi-continuous asset orchestration and renewal, including the redesign of routines remains, perhaps the most important managerial function. Though related to other managerial activity, entrepreneurial management required for business to possess dynamic capabilities was different in that it had nothing to do with standardized analysis and optimization. Instead, entrepreneurial management had more to do with figuring out the next big opportunity or challenge and how to address it. Entrepreneurial management was, therefore, not just about maintaining and refining procedures.

Porter's model of sustainable competitive advantage is derived from the industrial organization economic theory which opines that the structure, the degree of competitiveness as well as industry attractiveness is a product of imperfections in the market for instance existence of the costs of transaction as opposed to the assumption of perfect world as per the competitive model (Coase, 1937). The significance of Porter's model of sustainable competitive advantage to the current study is that it develops the basis of interaction between technological innovation, strategic leadership, and competitive advantage. It achieves this by suggesting that technological change is such an important influence on competitive advantage both because it creates new opportunities for competition and because it plays a central part in the existing competitive strategy through its ubiquitous presence in the value chain. Secondly, that change in the way office functions can be performed is one of the most important types of technological trends occurring today for many firms, though few are devoting substantial resources to it. Therefore, the theory will help inform Kenya's LTEs to understand how to create value for buyers and analyze competitive position based on value as opposed to cost.

Intellectual interest on the association between technological innovation, strategic leadership, and competitive positioning has developed in the recent past. Detelin, Judge and Wright (2015) conducted an international multi-cluster comparative study on the relationship between strategic leadership and executive innovation and found that strategic leadership behaviors had a strong positive relationship with executive influence on both product-market and administrative innovations. The study, however, adopted a desktop review design which relied on secondary data validity of which cannot be ascertained and, therefore, lacked the primary, first-hand information from the practitioners of strategic leadership and their perspectives informed by actual experience. To address this gap, the present study set out to obtain responses from strategic leaders across large telecommunication firms in the country for their first-hand information informed by actual experience.

Witjara, Herwany and Santosa (2019) viewed strategic innovation as a business development framework that is future-focused and one that identifies breakthrough growth opportunities, accelerates business decisions, and creates near-term, measurable impact within the context of a longer-term vision for sustainable competitive advantage. In the presence of strategic innovation, an organization is challenged to look beyond its established business. Therefore, strategic innovation is an important factor for achieving sustainable competitive advantage and financial performance by any given organization. According to Kuratko, Hornsby \& Hayton, (2015), innovations provide firms with a strategic orientation to overcome the problems they encounter while striving to achieve sustainable competitive advantage.

According to Mostafa (2020), intellectual simulation enables strategic leaders to enhance innovation and new idea generation. By implementing information technology aimed at increasing knowledge management performance, strategic leaders are able to close the gap between success and possible failure hence contribute to overall organizational performance. Therefore, strategic leaders have help to develop and nurture new ideas, and this is essential for strategic development in the organization. The role of executives is to lead in the implementation of information technology as role models thus enhancing knowledge management performance. Strategic leadership becomes a critical component in knowledge acquisition by facilitating knowledge transfer and simultaneously exploring more innovative solutions for organizational problems. Whenever executives embrace strategic leadership, they positively influence the knowledge accumulation process. Furthermore, strategic leaders help improve knowledge integration by facilitating knowledge sharing throughout the various organizational levels. More importantly, strategic leadership develop relationships and interactions within 
companies, set desired expectations, and inspire followers to identify further opportunities in their business environment.

In a study to investigate the role of strategic leadership in the academic environment, Mahdi and Almsafir (2014) used a sample of academic leaders and revealed that strategic leadership significantly and positively predicted organization's sustainable competitive advantage. According to a study by Hughes and Beatty (2011), strategic leadership is basically related to three key dimensions, which are think, act, and influence. This study concluded that strategic leadership has as its primary task, to drive the organization toward a long-run success via competitive advantage. On the other hand, the study found that strategic leadership was a significant predictor of strategic planning and strategic thinking. Furthermore, both strategic planning and strategic thinking were significantly related to competitive advantage. The overall finding of this study was that strategic planning and strategic thinking mediated the effect of strategic leadership on competitive advantage.

A study by Mohammad (2018) sought to investigate the effects embedded in a model comprised of four constructs: strategic leadership, strategic thinking, strategic planning and competitive advantage. The findings of this study confirmed that strategic leadership was significantly and positively related to strategic planning, strategic thinking, and competitive advantage. Moreover, strategic thinking and strategic planning were significantly and positively related to competitive advantage. The effect of strategic leadership on competitive advantage was mediated by strategic planning and by strategic thinking.

A study by Mugo \& Macharia (2020) sought to establish the effect of technological innovation on the competitive advantage of telecommunications firms in Kenya. To measure technological innovation, the study used development of Global System of Mobile (GSM) networks, new software and tools, and synergies and partnerships. The results of the research indicated innovation had a significant influence on the competitive advantage of information technology firms in Kenya.

In a different study, Zuraik (2017) sought in their study, to propose a strategic model for innovation leadership with evidence from transformational leadership practitioners in a supportive climate for fostering innovation performance. The study showed that transformational leadership behaviors of organizational leaders could aid in enabling and championing innovation in their organizations at organizational level. The study also found that the ambidextrous behavior of team leadership could affect innovation outcomes at the team level. The study, however, only narrowly focused on the transformational leadership style, overlooking other types of leadership that might also have a bearing on innovative leadership. To address this gap, the present study surveyed large telecommunication firms in the country seeking responses from executive leaders irrespective of their leadership styles.

Kisingú (2017) studied the role of strategic leadership in the attainment of a sustainable competitive advantage among Kenyan private and public universities and found a significant linkage between strategic leadership and sustainable competitive advantage among private and public universities in Kenya. The study, however, only assessed the direct linkage between strategic leadership and competitive advantage not accounting for technological innovation. In addition, in the study, competitive advantage was only indexed by qualitative measures including organizational excellence, organizational effectiveness and organizational responsiveness. This failed to account for Porters' five forces model of competitive advantage such as product differentiation and innovation as well as cost leadership, hence, the present study.

\section{Methodology}

Primary data for the study was gathered through the use of a semi-structured questionnaire. The questionnaires were developed in line with the objectives and hypotheses of the study and guided by the literature reviewed on the concepts of the study as well as theories upon which the study was anchored on. Questions were designed to cover several aspects of strategic leadership, technological innovation, and competitive advantage. The tool contained only close-ended items. The close-ended items were used with the aim of providing responses that were in some way structured for effective statistical analysis, hypothesis testing, and drawing of conclusions.

The data for this study was collected during the unprecedented period of Corana Virus Disease of 2019 (famously referred to as COVID-19) pandemic and, therefore, involved using a mix of strategies, as the respondents deemed appropriate. The instruments were dropped and picked later. However, in circumstances where respondents requested for alternative modes like emails as sometimes physical interactions were unattainable, the researcher made arrangements and shared with them the instrument in soft copy, which was completed, stamped, scanned, and finally emailed back by the respondents. All the 83 large telecommunication firms were approached and served with the questionnaire out of which 61 filled and returned the questionnaires yielding a response rate of $73.5 \%$. 
One respondent per one large telecommunication firm in Kenya was targeted to respond to the questionnaire. Zikmund (2012) argued that one strategic leader/Chief Executive Officer (CEO) per organization is sufficient as they are in a position to understand organization's internal and external operations. This ensured reliability, objectivity, and consistency of responses from each large telecommunication firm in Kenya. A five-point Likert-type scale varying from no extent (1) to (5) very large extent was adopted to construct some of the items. Likert-type scale questions are the most frequently used variation of the summated rating scale. It is used to test a respondent's perception or attitudes. On one extreme is favourable while on the other is unfavourable perception towards an aspect of the study.

\section{Results}

Table 1. Model summary for test of moderating influence of strategic leadership on the relationship between technological innovation and competitive advantage

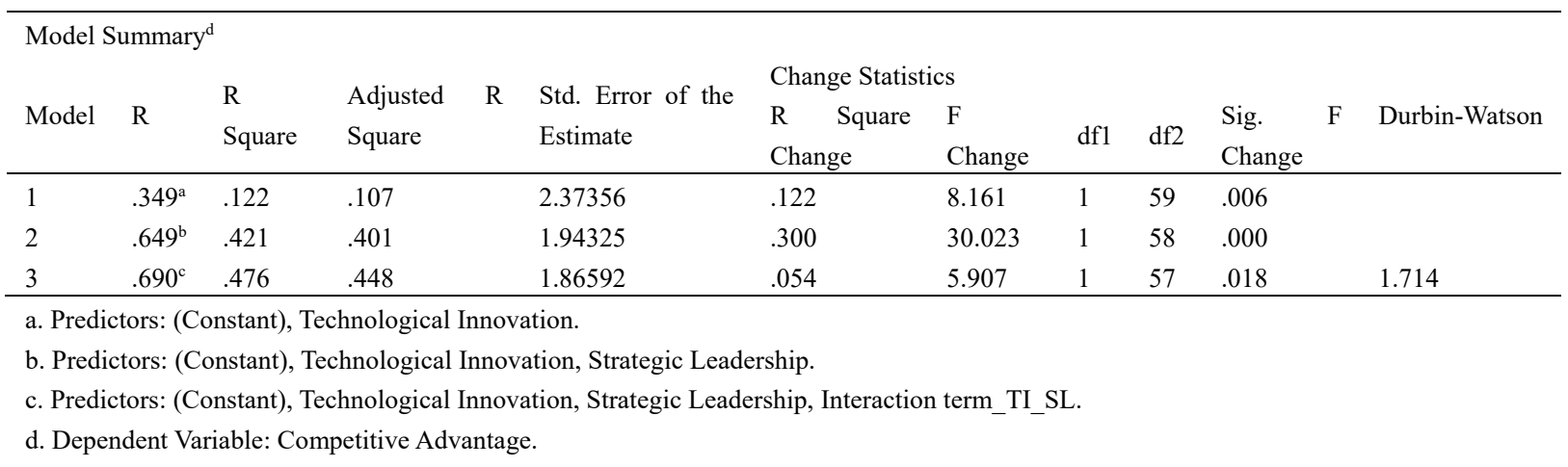

Table 1 shows that technological innovation explained $12.2 \%$ of the variation in competitive advantage (model 1). Model 2 suggests that technological innovation and strategic leadership as independent variables jointly explained $42.1 \%$ of the variation in competitive advantage. Strategic leadership had significant contribution in explaining variation in competitive advantage $\left(\mathrm{R}^{2}\right.$ change $\left.=.300\right)$. By introducing interaction term (in model 3$)$, $\mathrm{R}^{2}$ increased to .476 . This implied that technological innovation, strategic leadership, and interaction term accounts for $47.6 \%$ of the variation in competitive advantage. There is a significant $\mathrm{R}^{2}$ change of .054 . The ANOVA test results are as presented in Table 2.

Table 2. ANOVA results for the moderating influence of strategic leadership on the relationship between technological innovation and competitive advantage

\begin{tabular}{|c|c|c|c|c|c|c|}
\hline \multicolumn{7}{|c|}{$\mathrm{ANOVA}^{\mathrm{a}}$} \\
\hline \multicolumn{2}{|c|}{ Model } & \multirow{2}{*}{$\begin{array}{l}\text { Sum of Squares } \\
45.977\end{array}$} & \multirow{2}{*}{$\frac{\mathrm{df}}{1}$} & \multirow{2}{*}{$\frac{\text { Mean Square }}{45.977}$} & \multirow{2}{*}{$\frac{F}{8.161}$} & \multirow{2}{*}{$\frac{\text { Sig. }}{.006^{\mathrm{b}}}$} \\
\hline & Regression & & & & & \\
\hline \multirow[t]{3}{*}{1} & Residual & 332.393 & 59 & 5.634 & & \\
\hline & Total & 378.370 & 60 & & & \\
\hline & Regression & 159.349 & 2 & 79.675 & 21.099 & $.000^{\mathrm{c}}$ \\
\hline \multirow[t]{3}{*}{2} & Residual & 219.020 & 58 & 3.776 & & \\
\hline & Total & 378.370 & 60 & & & \\
\hline & Regression & 179.916 & 3 & 59.972 & 17.225 & $.000^{\mathrm{d}}$ \\
\hline \multirow[t]{2}{*}{3} & Residual & 198.454 & 57 & 3.482 & & \\
\hline & Total & 378.370 & 60 & & & \\
\hline
\end{tabular}

\footnotetext{
a. Dependent Variable: Competitive Advantage.

b. Predictors: (Constant), Technological Innovation.

c. Predictors: (Constant), Technological Innovation, Strategic Leadership.

d. Predictors: (Constant), Technological Innovation, Strategic Leadership, Interaction term_TI_SL.
} 
Results in Table 2 show that model 1 depicting the model expressing the relationship between technological innovation and competitive advantage was significant in overall $(\mathrm{F}=8.161, \mathrm{p}$-value $=.006<0.05)$. Model 2 depicting the combined influence of technological innovation and strategic leadership on competitive advantage was significant in overall and robust $(\mathrm{F}=21.099, \mathrm{p}$-value $=0.000<0.05)$. Model 3 , when interaction term was introduced the relationship was also significant in overall $(\mathrm{F}=17.225$, $\mathrm{p}$-value $=0.000<0.05)$. Results for the regression coefficients which form the basis for interpretation of the hypothesis are presented in Table 3.

Table 3. Regression coefficients for the moderating influence of strategic leadership on the relationship between technological innovation and competitive advantage

\begin{tabular}{|c|c|c|c|c|c|c|}
\hline \multicolumn{7}{|c|}{ Coefficients $^{\mathrm{a}}$} \\
\hline \multirow{2}{*}{\multicolumn{2}{|c|}{ Model }} & \multicolumn{2}{|c|}{ Unstandardized Coefficients } & \multirow{2}{*}{$\begin{array}{l}\text { Standardized Coefficients } \\
\text { Beta }\end{array}$} & \multirow{2}{*}{$\mathrm{t}$} & \multirow{2}{*}{ Sig. } \\
\hline & & B & Std. Error & & & \\
\hline \multirow{3}{*}{1} & (Constant) & 9.599 & 2.990 & & 3.210 & .002 \\
\hline & Technological Innovation & .438 & .153 & .349 & 2.857 & .006 \\
\hline & (Constant) & 3.915 & 2.659 & & 1.472 & .146 \\
\hline \multirow[t]{3}{*}{2} & Technological Innovation & .250 & .130 & .199 & 1.920 & .060 \\
\hline & Strategic Leadership & .491 & .090 & .567 & 5.479 & .000 \\
\hline & (Constant) & 29.546 & 10.851 & & 2.723 & .009 \\
\hline \multirow{3}{*}{3} & Technological Innovation & -1.097 & .568 & -.872 & -1.931 & .058 \\
\hline & Strategic Leadership & -.952 & .600 & -1.101 & -1.587 & .118 \\
\hline & Interaction term $\mathrm{TI}$ SL & .075 & .031 & 2.220 & 2.430 & .018 \\
\hline
\end{tabular}

a. Dependent Variable: Competitive Advantage.

The results in Table 3 demonstrated that in model 1 strategic leadership had a significant influence on competitive advantage $(\beta=.349, \mathrm{p}$-value $\leq 0.05)$. Model 2 revealed that strategic leadership had stronger significant influence than technological innovation in explaining competitive advantage $(\beta=.567$, p-value $=0.000<0.05)$. Model 3 revealed that the interaction term had a stronger significant influence on the relationship between technological innovation and competitive advantage $(\beta=2.220, p$-value $=0.018<0.05)$. The results, therefore, supported the hypothesis, which stated that strategic leadership had a significant moderating role on the relationship between technological innovation and competitive advantage. Table 4 presents a summary of the test results for the hypothesis.

Table 4. Summary test results for the hypothesis

\begin{tabular}{|c|c|c|c|c|c|}
\hline Hypothesis & Beta & $\mathbf{R}$ & $\mathbf{R}^{2}$ & Sig. & Conclusion \\
\hline $\begin{array}{l}\mathrm{H}_{2} \text { : Strategic leadership has a significant moderating role on the } \\
\text { relationship between technological innovation and competitive } \\
\text { advantage }\end{array}$ & 2.220 & .690 & .476 & 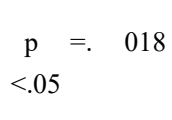 & $\mathrm{H}_{2}$ Supported \\
\hline
\end{tabular}

The summary results in Table 4 revealed that strategic leadership significantly moderates the relationship between technological innovation and competitive advantage. This was supported by a statistically significant standard beta coefficient of the interaction term of 2.220 , p-value $=0.018<0.05$ ), $\mathrm{R}^{2}$ change $=0.054$ ) and $\mathrm{F}=5.907$. The three regression models were as follows:

$\mathrm{CA}_{1}=9.599+.349 \mathrm{TI}$

$\mathrm{CA}_{2}=3.915+.199 \mathrm{TI}+.567 \mathrm{SL}$

$\mathrm{CA}_{3}=29.546-.872 \mathrm{TI}-1.101 \mathrm{SL}+2.220 \mathrm{TI} * \mathrm{SL}$

Where: $\mathrm{CA}=$ Competitive Advantage, $\mathrm{TI}=$ Technological Innovation, $\mathrm{SL}=$ Strategic Leadership

\section{Conclusion}

The objective of the study was to determine the moderating role of strategic leadership on the relationship between technological innovation and competitive advantage. This in turn led to the hypothesis of the study, stated as H: Strategic leadership has a significant moderating role on the relationship between technological innovation and competitive advantage. To address the objective and test the hypothesis, the moderating variable, 
strategic leadership, was measured by two sub-constructs, that is, strategic direction and organization controls.

The study proceeded to test the hypothesis by running a stepwise regression analysis, whose results revealed that the interaction term had a strong influence on the relationship between technological innovation and competitive advantage significantly $(\beta=2.220$, $\mathrm{p}$-value $\leq 0.05)$, therefore, meeting the conditions for moderation. The beta coefficient implied that for every $1 \%$ change in the interaction term between technological innovation and strategic leadership, there was a corresponding $22.2 \%$ change in competitive advantage across the telecommunication firms surveyed. The results, therefore, supported the hypothesis.

The study findings are supported by Detelin, Judge and Wright (2015) who conducted an international multi-cluster comparative study on the relationship between strategic leadership and executive innovation and found that strategic leadership behaviors had a strong positive relationship with executive influence on both product-market and administrative innovations.

The finding also in concurrence with Zuraik (2017) who showed that transformational leadership behaviors of organizational leaders aided in enabling and championing innovation in their organizations at organizational level. The study also found that the ambidextrous behavior of team leadership can impact innovation outcomes at the team level. The finding is further supported by Kisingú (2017) who studied the role of strategic leadership in the attainment of a sustainable competitive advantage among Kenyan private and public universities and found a significant linkage between strategic leadership and sustainable competitive advantage among private and public universities in Kenya.

The present study findings are in support of the findings reported by Al-zoubi (2012) who investigated leadership competencies and competitive advantage with empirical study of Jordan telecommunications. The study revealed that leadership competences had a significant impact on competitive advantage of the Jordanian telecommunication companies in the Jordanian market, as well an existence relationship between leadership competences and competitive advantage. The study observed that organizations depend upon capable, strategic and visionary leadership to guide them through unprecedented changes. Leadership competencies are a requirement for most organizations in today's competitive market place. Nowadays senior leaders are facing tough decisions that have far-reaching consequences; they are looking to grow and expand by improving the organization's leadership capabilities, thinking, and planning.

The findings are also in agreement with the study by Mohammad (2018) that investigated the effects embedded in a model comprised of four constructs: strategic leadership, strategic thinking, strategic planning and competitive advantage. The findings of this study confirmed that strategic leadership was significantly and positively related to strategic planning, strategic thinking and competitive advantage. Moreover, strategic thinking and strategic planning were significantly and positively related to competitive advantage. The effect of strategic leadership on competitive advantage was mediated by strategic planning and strategic thinking.

The findings are also in conformity with Mostafa (2020) who opined that executives as strategic leaders enhance innovation and new idea generation through intellectual stimulation. Executives can contribute to overall organizational performance through implementing information technology to increase knowledge management performance and help close the gap between success and possible failure.

Strategic leaders have a crucial role in developing and nurturing new ideas, and this is essential for strategic development in the organization. The finding of the current study is also in harmony with Mahdi and Almsafir (2014) who investigated the role of strategic leadership in the academic environment using a sample of academic leaders and revealed that strategic leadership significantly and positively predicted organization's sustainable competitive advantage.

The findings of the research are in tandem with Mugo \& Macharia (2020) who sought to establish the effect of technological innovation on the competitive advantage of telecommunications firms in Kenya. To measure technological innovation, the study used development of Global System of Mobile (GSM) networks, new software and tools, and synergies and partnerships. The results of the research indicated innovation had a significant influence on the competitive advantage of information technology firms in Kenya.

The findings are in support of the technological networks theory of innovation as proposed by Rogers (1983) and opines that technological innovation is primarily driven in both internal and external means. Accordingly, the finding revealed that strategic leadership constitutes a notable internal driver of technological innovation leading to competitive advantage, consistent with the theory's assertion that internally, innovation is driven by both organizational leadership and knowledge-intensive departments such as information technology and the human resource itself. Strategic leaders are also instrumental in deciding how organizations leverage technological 
innovation in response to environmental changes and externalities, which are further in tandem with Rogers' (1983) assertion that externally, innovation is driven by the way organizations respond to changes in process necessary for value addition.

The study concluded that whereas technological innovation and strategic leadership each influence competitive advantage, their combined influence on the latter is more than their individual effects. In other words, as compared to technological innovation alone, strategic leadership accounts for the greatest variability in the competitive advantage of an organization. Perhaps, this is the most intriguing finding of this study and can be attributed to the overriding effect of strategic leadership as a centermost variable towards the attainment of competitive advantage as compared to any other variable. As the decision makers, organizational leaders determine the extent to which technological innovation takes place in an organization which in turn influence the competitive advantage thereof.

The study also concluded that change in strategic leadership would affect the strength of relationship between technological innovation and competitive advantage. This can be attributed to the importance of organizational leadership's role as decision makers and key enablers of technological innovation among large telecommunication enterprises through support by offering direction, controls, resource mobilization, mentorship, recognition and provision of autonomy among staff to innovate. As opposed to hierarchical leadership with regard to innovation, strategic leadership creates a network of innovators within and outside the organization leading to a collective and continuous innovation process resulting in the creation of technologically innovative products and services and eventually competitive advantage that earns the organization an increased customer base and market share.

\section{Implication of the Study}

The study presented notable implications on the policy framework, the strategic management practice, and theory implications in the telecommunication industry and beyond. At policy level, the Government of Kenya would benefit from the study by ensuring that policy makers and regulatory authorities in the telecommunication sector formulate policies that would promote technological innovation and strategic leadership for enhancing competitive advantage.

The study further found that strategic leadership significantly moderates the relationship between technological innovation and competitive advantage among firms in the telecommunication industry in Kenya. As such, the study recommends that managerial practitioners in the telecommunication firms in Kenya institutionalize innovation and leadership by creating the requisite direction and controls that enable the emergence of innovation, leadership, and value creation for sustainable competitive advantage.

The study findings' implications further extended, supported, and added value on the theories adopted by the study. For instance, the findings were in support of the dynamic capabilities' theory postulated by Teece et. al., (1997), that held that if the unique resources owned by an organization are well utilized, they can lead to a competitive position. Additionally, technological networks theory of innovation which was proposed by Rogers (1983) and opined that technological innovation is primarily driven in both internal and external means was also supported. Further, the findings were consistent with Porter's model of sustainable competitive advantage (Porter, 1985). Telecommunication firms, therefore, should leverage both product differentiation and innovation as well as cost leadership to earn competitive advantage and acquire more customers.

\section{Acknowledgement}

I respectfully acknowledge my co-authors: Prof. Zachary B. Awino, Prof. Martin Ogutu, and Dr. Joseph O. Owino for their dedication, guidance, and intellectual contributions which were immeasurable. I also want to acknowledge the study respondents who made the study possible. I sincerely thank you for your contributions and hold you in the highest esteem ever.

\section{References}

Adede, A. O., Kibera, F. N., \& Owino, J. O. (2017). Electronic marketing practices, competitive environment and performance of telecommunications companies in kenya. British Journal of Marketing Studies, 5(5), 60-67.

Al-zoubi, M. (2012). Leadership competencies and competitive advantage: empirical study of Jordan telecommunications. European Journal of Business and Management, 4(7), 234-247.

Awino, Z. B. (2013). Strategic planning and competitive advantage of ICT small and medium enterprises in Kenya. Business and Management Horizons, 1(1), 191-204. 
Coase, R. H. (1937). The nature of the firm. Economica, 4(16), 386-405.

Communications Authority of Kenya - CA. (2020). Fourth quarter sector statistics report for the financial year 2019/2020. Retrieved from https://ca.go.ke/wp-content/uploads/2020/07/Sector-Statistics-Report-Q3-2019-2020-.pdf

Detelin, S. E., Judge, W., \& Wright, P. (2015). Strategic leadership and executive innovation influence: an international multi-cluster comparative study. Strategic Management Journal, 26(7), 665-682. https://doi.org/10.1002/smj.469

Gathi, W. R. (2018). Transformational leadership, knowledge management, organizational structure, reward systems and performance of telecommunication firms in Kenya, (Unpublished PhD Thesis). University of Nairobi.

Government of Kenya. (2007). Kenya vision 2030: a globally competitive and prosperous Kenya. Government printers, Nairobi, Kenya.

Herden, T. T. (2020). Explaining the competitive advantage generated from analytics with the knowledge-based view: the example of logistics and supply chain management. Business Research, 13, 163-214. https://doi.org/10.1007/s40685-019-00104-x

Hughes, R., \& Beatty, K. (2011). Becoming a strategic leader: your role in your organization's enduring success. S.F., Jossy-Bass, Wiley \& Sons, Inc.

Institute of Economic Affairs. (2018). The telkom sector in Kenya: a historical journey from 1999 to date. Nairobi, Kenya.

Kanyuga, L. (2019). Influence of strategic innovation on performance of telecommunication firms: a case of Safaricom Company. Journal of Strategic Management, 3(1), 21-39.

Karlsson, C., Johansson, B., \& Stough, R. (2013). Innovation, technology and knowledge. New York, Routledge.

Kiptui, J. K. (2017). Innovation, structure, environment, competitive advantage and performance of commercial banks in Kenya, (Unpublished PhD Thesis). University of Nairobi.

Kising'u, T. M. (2017). Role of strategic leadership for sustainable competitive advantage in Kenyan public and private universities (Unpublished PhD Thesis). Jomo Kenyatta University of Agriculture and Technology.

Kuratko, D. F., Hornsby, J. S., \& Hayton, J. (2015). Corporate entrepreneurship: the innovative challenge for a new global economic reality. Small Business Economics, 45(2), 245-253.

Kuusisto, J., \& Meyer, M. (2015). Insights into services and innovation in the knowledge-intensive economy. Technology Review 134/2003, Tekes National Technology Agency, Helsinki.

Mahdi, O., \& Almsafir, M. (2014). The role of strategic leadership in building sustainable competitive advantage in the academic environment. Procedia-Social and Behavioral Sciences, 129, 289-296. https://doi.org/10.1016/j.sbspro.2014.03.679

Mohammad, H. (2018). Impact of strategic leadership on strategic competitive advantage through strategic thinking and strategic planning: a bi-meditational research. Business: Theory and Practice, 19, 322-330. https://doi.org/10.3846/btp.2018.32

Mostafa, S. (2020). Transformational leadership, information technology, knowledge management, firm performance: how are they linked? The Journal of Values-Based Leadership, 13(2), 17. https://doi.org/10.22543/0733.132.1317

Mugo, P., \& Macharia, J. (2020). Technological innovation and competitive advantage in telecommunications companies. International Journal of Research in Business \& Social Science, 9(5), 38-47. https://doi.org/10.20525/ijrbs.v9i5.866

Nyawade, F. O. (2015). Effect of leadership styles and organizational culture on the relationship between innovation and performance of firms listed on the Nairobi securities exchange (Unpublished PhD Thesis), University of Nairobi.

Oughton, E., Frias, Z, Russell, T, Sicker, D., \& Cleevely, D. D. (2018). Towards 5G: scenario-based assessment of the future supply and demand for mobile telecommunications infrastructure. Technological Forecasting \& Social Change, 133, 141-155. https://doi.org/10.1016/j.techfore.2018.03.016

Porter, M. E. (1980). Competitive strategy, New York, Free Press. 
Porter, M. E. (1985). Competitive strategy. New York, Free Press.

Porter, M. E. (1990). The competitive advantage of nations. Harvard Business Review. Retrieved from https://hbr.org/1990/03/the-competitive-advantage-of-nations

Porter, M. E. (1998). Competitive strategy: techniques for analyzing industries and competitors. New York, NY, Free Press. https://doi.org/10.4324/9781912281060

Porter, M. E. (1998). What is strategy? Harvard Business Review, 74(6), 61-78.

Rogers, E. M. (1983). Diffusion of innovations (4th ed.). New York: The Free Press.

Teece, J. D. (2012). Dynamic capabilities: routines versus entrepreneurial action. Journal of Management Studies, 49, 8. https://doi.org/10.1017/jmo.2017.75

Teece, J. D., Pisano, G., \& Shuen, A. (1997). Dynamic capabilities and strategic management. Strategic $\begin{array}{llll}\text { Management } & \text { Journal, } & \text { 509-533. }\end{array}$ https://doi.org/10.1002/(SICI)1097-0266(199708)18:7<509::AID-SMJ882>3.0.CO;2-Z

Un, C. A., \& Asakawa, K. (2015). Types of research and development collaborations and process innovation: the benefit of collaborating upstream in the knowledge chain. The Journal of Product Innovation Management, 32(1), 138-153. https://doi.org/10.1111/jpim.12229

Witjara, E., Herwany, A., \& Santosa, S. P. (2019). The influence of industry environment and company asset on strategic innovation and the implication on business valuation of digital industry in Indonesia. Sustainable Collaboration in Business, Technology, Information and Innovation (Scbtii).

World Economic Outlook (WEO) Report. (2019). Retrieved from https://www.imf.org/en/Publications/WEO/Issues/2019/07/18/WEOupdateJuly2019

Yalla, A. J. (2015). The influence of corporate political activity and competitive strategy on the relationship between innovative capability and performance of large manufacturing firms in Kenya (Unpublished PhD Thesis). University of Nairobi.

Zikmund, W., Babin, B., Carr, J., \& Griffin, M. (2012). Business research methods. Cengage Learning.

Zuraik, A. (2017). A strategic model for innovation leadership- ambidextrous and transformational leadership with a supportive climate to foster innovation performance. Retrieved from https://www.researchgate.net/publication/315644457_A_Strategic_Model_for_Innovation_Leadership

\section{Copyrights}

Copyright for this article is retained by the author(s), with first publication rights granted to the journal.

This is an open-access article distributed under the terms and conditions of the Creative Commons Attribution license (http://creativecommons.org/licenses/by/4.0/). 